\title{
ANALISIS PERAN KARYAWAN DALAM HUBUNGAN ANTARA DUKUNGAN PIMPINAN DENGAN FEKTIVITAS SPIP DAN KUALITAS LAPORAN KEUANGAN
}

\author{
Sudarno \\ Departemen Akuntansi, Fakultas Ekonomika dan Bisnis, Universitas Diponegoro
}

\begin{abstract}
The implication of issuance of Law No. 17/ 2003 on State Finance and Law No $71 / 2010$ on Government Accounting Standard (SAP), the state universities have to compile and present finansial statements. The purposes of this research are to investigate factors which are affecting the quality of finansial statement, the role of effectiveness SPIP to the effect of and to identify the characteristic of develop a finansial statement and level of leadership supported at state higher education in Jawa Tengah and DI Yogyakarta. Population of this research was the accounting division responsible for preparing financial statements in 15 state universities in Jawa Tengah and DI Yogyakarta. Assuming each division had 7 staff; questionnaires were distributed by posts and couriers to 105 staff. Data from 67 respondents $(63,81 \%)$ were analyzed by path analysis by using PLS 2.0. This study supported the role of efectivness SPIP in developing a high quality of finansial statement. The commitment and motivation affects to quality of finansial statement indirectly through efectivness SPIP. However, this research has not enough evidence to said that competency affects to efectivness SPIP. The other, The results of this study tend to support mediation hypothesis that leadership supported affects to efectivness SPIP and quality of finansial statement indirectly through competency, commitment and motivation.
\end{abstract}

Keywords: quality of finansial statement, the role of efectivness SPIP, competence, commitment, motivation, and leadership supported.

\section{PENDAHULUAN}

Amanat UU No.17 Tahun 2003,

Keuangan Negara dikelola secara tertib, taat pada peraturan perundang-undangan, efisien, ekonomis, efektif, transparan, dan bertanggung jawab. Dalam rangka pertanggungjawaban atas pengelolaan keuangan pemerintah, setiap entitas pelaporan wajib menyusun dan menyajikan laporan keuangan. Laporan keuangan meliputi Laporan Realisasi APBN, Neraca, Laporan Arus Kas, dan Catatan atas Laporan Keuangan. Laporan Keuangan harus diperiksa oleh Badan Pemeriksa Keuangan (BPK). Pemeriksaan keuangan negara meliputi pemeriksaan atas pengelolaan keuangan negara dan pemeriksaan atas tanggung jawab keuangan negara.

Sebagaimana dinyatakan dalam Peraturan Badan Pemeriksa Keuangan Republik Indonesia No. 1 tahun 2017 bahwa peran BPK membantu pemerintah dalam mempertanggungjawabkan pengelolaan keuangan negara dan sekaligus membantu wakil rakyat (DPR) memperoleh informasi keuangan yang tidak menyesatkan sehingga 
dapat digunakan untuk membuat keputusan yang akurat. Tujuan pemeriksaan laporan keuangan adalah untuk menyatakan pendapat (opini) tentang kewajaran dalam semua hal yang material. Jenis-jenis opini adalah wajar tanpa pengecualian (WTP), WTP dengan bahasa penjelas, wajar dengan pengecualian (WDP), tidak wajar (TW), dan tidak memberikan pendapat (TMP). Pemberian opini di atas berdasarkan kriteriakriteria yang umum digunakan oleh para pemeriksa (auditor). Kriteria tersebut adalah

$$
\text { (1) materialitas dari kesalahan, }
$$

pencatatan transaksi sesuai ketentuan standar akuntansi pemerintah (SAP), (3) tidak ada batasan pada pemeriksa, (4) kepatuhan pada peraturan, (5) sistem pengendalian intern pemerintah (SPIP) memadai, dan (6) pengungkapan yang memadai.

Perguruan tinggi negeri (PTN) merupakan salah satu instansi pemerintah yang diperiksa oleh BPK. PTN merupakan unit organisasi sebagai penghasil sumber daya manusia (SDM) yang berkualitas dan kompeten, khususnya dalam bidang akuntansi. Harapannya PTN dapat mempertangungjawabkan pengelolaan keuangan dengan baik dan berkualitas. Realitasnya, beberapa PTN mempertangungjawabkan pengelolaan keuangan kurang baik. Contoh adalah opini laporan keuangan Kemenristekdikti. Kemenristekdikti merupakan salah satu kementrian di lingkungan pemerintahan yang bertindak selaku Pengguna Anggaran/Pengguna Barang sehingga setiap tahun harus menyusun dan menyajikan laporan keuangan serta diperiksa oleh BPK. Opini BPK atas laporan keuangan Kemenristekdikti 2 tahun Ristek, Dikbud tahun 2010 adalah WTP, TMP, tahun 2011 beropini WTP, TMP, tahun 2012 beropini WTP, WDP, tahun 2013 adalah WDP, WTP, dan tahun 2014 beropini WTP-DPP, WTP.

Berkenaan dengan opini laporan keuangan di atas maka laporan keuangan Kemenristekdikti menunjukkan kualitas laporan keuangan yang kurang baik. Penyebab kualitas laporan keuangan yang rendah berkaitan dengan penerapan SAP, pengungkapan, taat peraturan, dan keandalan SPIP, pemeriksaan oleh Inspektorat Jendral Pendidikan Tinggi (Itjen) atau BPK, dan penggunaan Sistem Akuntansi Instansi Berbasis Akrual (SAIBA) dalam proses menyusun dan menyajikan laporan keuangan. SAIBA bukan penyebab rendahnya kualitas laporan keuangan Kemenristekdikti karena SAIBA digunakan oleh seluruh instansi pemerintah. Demikian pula pembatasan ruang lingkup 
audit bukan penyebab rendahnya kualitas laporan keuangan. Hal ini karena pemeriksa laporan keuangan (BPK atau Itjen) mempunyai otoritas yang tinggi dalam melaksanakan audit. Jadi penyebab kualitas laporan keuangan berkaitan dengan masalah penerapan SAP, pengungkapan, taat peraturan, dan keandalan SPIP. Hal ini itemitem tersebut bekaitan dengan perilaku individu yang terlibat dalam proses penyusunan dan penyajian laporan keuangan. Proses penyusunan dan penyajian laporan keuangan melibatkan individuindividu yang tergabung dalam Bagian Keuangan atau Bagian Akuntansi. Karenanya, individu berkenaan harus mempunyai pengetahuan tentang SAP dan kemampuan khusus untuk membuat pengungkapan yang ringkas dan jelas. Selain itu mereka harus memiliki komitmen dan motivasi yang tinggi karena tekanan waktu penyelesaian dan penyampaian laporan keuangan untuk dikonsolidasikan.

Dalam menghasilkan laporan keuangan yang berkualitas perlu dukungan SPIP yang memadai. SPIP yang baik akan memberikan: (1) keandalan pelaporan keuangan, (2) pengamanan aset negara, (3) ketaatan terhadap peraturan perundangundangan, dan (4) pengelolaan keuangan yang efektif dan efisien. Dalam SPIP, elemen pimpinan merupakan payung yang menaungi elemen yang lain. Maknanya elemen SPIP yang lain sangat tergantung baik tidaknya elemen SPIP yang berupa lingkungan pengendalian dalam hal ini integritas atau komitmen pimpinan. Untuk memperkuat penyelenggaraan SPIP perlu dilakukan pengawasan intern dan pembinaan. Pengawasan intern dan pembinaan dilakukan oleh aparat pengawasan intern pemerintah (APIP) dimana pengawasan intern melalui audit, reviu, evaluasi, pemantauan, dan kegiatan pengawasan lainnya. Selain itu, perlu mengidentifikasi pengetahuan penyusun laporan keuangan, komitmen mereka terhadap institusi dan motivasi kerja karyawan berkenaan. Lebih penting lagi, sebagaimana elemen SPIP pertama, yaitu lingkungan pengendalian maka dukungan pimpinan dalam proses penyusunan laporan keuangan sangat diperlukan. Karenanya, terdapat beberapa hal yang perlu dikaji terkait dengan kualitas laporan keuangan, yaitu: kinerja APIP, efektivitas SPIP, dukungan pimpinan, kompetensi SDM, komitmen organisasi, dan motivasi kerja karyawan penyusun laporan keungan.

\section{TINJAUAN PUSTAKA DAN PENGEMBANGAN HIPOTESIS}




\section{Teori Sikap dan Perilaku}

Perilaku ditentukan oleh sikap. Selain itu perilaku dipengaruhi oleh aturan sosial, kebiasaan, dan konsekuensi yang ada. Sikap berupa apa yang ingin lakukan. Aturan sosial ialah apa yang mereka pikirkan ketika mereka akan melakukan sesuatu. Kebiasaan berupa apa yang mereka biasa lakukan. Konsekuensi merupakan akibat dari perilaku dari mereka, baik konsekwensi menguntungkan atau konsekwensi merugikan. Model perilaku bahwa faktor sosial, kebiasaan, dan konsekuensi yang dirasakan dapat mempengaruhi sikap dan selanjutnya akan wujud dalam perilaku (Triandis, 1980, 1994). Dalam kontek penelitian ini, penyusun laporan keuangan akan (berperilaku) melaksanakan tugas secara perfek (sempurna) jika individu (SDM) mempunyai, kompetensi, komitmen dan motivasi yang tinggi (perasaan/sikap) apalagi ditunjang oleh situasi dan kondisi sistem pengendalian intern pemerintah (SPIP) yang efektif. Perilaku SDM yang baik dan pelaksanaan SPIP yang efektif perlu mendapat dukungan dan perhatian dari pimpinan karena pimpinan yang punya kuasa atas penetapan SDM dan operasionalisasi proses penyusunan laporan keuangan.

\section{Hubungan Efektivitas SPIP dan Laporan}

\section{Keuangan}

Laporan Keuangan adalah bentuk pertanggungjawaban pengelolaan keuangan. Menurut PP 71 Tahun 2010, tujuan umum laporan keuangan yaitu menyajikan informasi mengenai posisi keuangan, realisasi anggaran, saldo anggaran lebih, arus kas, hasil operasi, dan perubahan ekuitas. Tujuan laporan keuangan menurut Ikatan Akuntan Indonesia (2012) yaitu menyediakan informasi yang menyangkut posisi keuangan, kinerja, serta perubahan posisi keuangan suatu perusahaan yang bermanfaat bagi sejumlah besar pemakai dalam pengambilan keputusan ekonomi. Kualitas laporan keuangan berkaitan dengan tingkat keandalan laporan keuangan. Ada empat karakteristik kualitatif laporan keuangan dan satu sifat laporan keuangan sebagai komponen dari keandalan laporan keuangan. Komponen kualitas laporan keuangan, yaitu: relevan; andal; dapat dibandingkan; dan dapat dipahami serta laporan keuangan bersifat tepat waktu. Keandalan laporan keuangan berhubungan dengan pelaksanaan Sistem Pengendalian Intern Pemerintah (SPIP) yang dirancang oleh organisasi. SPIP merupakan proses yang integral pada tindakan dan kegiatan yang dilakukan secara terus menerus oleh 
pimpinan dan seluruh pegawai untuk memberikan keyakinan memadai atas tercapainya tujuan organisasi melalui kegiatan yang efektif dan efisien, keandalan pelaporan keuangan, pengamanan aset negara, dan ketaatan terhadap peraturan perundang-undangan. Unsur SPIP terdiri atas: (a) lingkungan pengendalian; (b) penilaian risiko; (c) kegiatan pengendalian; (d) informasi dan komunikasi; dan (e) pemantauan pengendalian intern. Berdasarkan tujuan pembuatan SPIP yaitu memberikan keyakinan memadai atas keandalan pelaporan keuangan maka kualitas laporan keuangan ditentukan oleh efektif-tidaknya pelaksanaan SPIP. Dengan kata lain, efektivitas SPIP berpengaruh terhadap kualitas laporan keuangan. Jika efektivitas SPIP tinggi maka kualitas laporan keuangan diharapkan tinggi pula. Bukti empiris bahwa ketersediaan sarana dan prasarana (SPIP) berdampak signifikan positif pada kualitas laporan keuangan (Purwaniati dan Subaweh, 2011). Menurut Sukmaningrum dan Harto (2012) bahwa internal control systems berpengaruh signifikan positif pada local government financial statement quality. Berdasarkan konsep hubungan SPIP dengan kualitas laporan keuangan dan bukti empiris maka disusun hipotesis sebagai berikut.
H1: Pelaksanaan SPIP yang efektif akan meningkatan kualitas laporan keuangan.

\section{Hubungan Kualitas SDM, Efektivitas SPIP dan Laporan Keuangan}

SDM merupakan pelaksana atau operator dari proses penyusunan laporan keuangan termasuk didalamnya menjalankan SPIP yang telah dirancang oleh organisasi. Ini bermakna kualitas SDM berpengaruh terhadap kualitas laporan keuangan. Menurut Purwaniati dan Subaweh (2011) bahwa pengetahuan pengelola UAPPA E1 dan UAPPB berpengaruh signifikan positif terhadap kualitas laporan keuangan. Penelitian lain, Siti dkk. (2013) menyatakan bahwa komitmen organisasi dan kompentensi SDM berdampak secara signifikan positif terhadap kualitas Rencana Bisnis dan Anggaran (RBA). Hasil penelitian Sukmaningrum dan Harto (2012) menunjukkan quality of human resources tidak berpengaruh terhadap local government financial statement quality. Penelitian lain, Siti dkk. (2013) menyatakan bahwa motivasi kerja tidak berpengaruh terhadap kualitas RBA.

Berdasarkan hasil penelitian atas hubungan langsung SDM dengan kualitas laporan keuangan yang tidak konsisten dan merujuk teori sikap dan perilaku bahwa 
karyawan punya kompetensi, komitmen kerja, dan motivasi karyawan sebagai wujud sikap serta efektivitas SPIP sebagai hasil dalam perilaku maka tidak ada hubungan langsung antara SDM dengan kualitas laporan keuangan. Selain itu, pelaksanaan SPIP berupa tindakan dan kegiatan yang dilakukan secara terus menerus oleh pegawai. Ini berarti SDM merupakan faktor dominan yang mempengaruhi efektivitas SPIP. Penelitian ini memandang kualitas SDM dari sisi kompetensi, komitmen kerja, dan motivasi karyawan.

Kompetensi SDM merupakan keselarasan antara keahlian yang dimiliki karyawan dengan tugas yang diberikan oleh pimpinan. Tugas karyawan bagian akuntansi berupa tindakan dan kegiatan pelaksanaan SPIP yang dilakukan secara terus menerus. Hasil penelitian Siti dkk. (2013) menunjukkan bahwa kompetensi SDM meningkatkan kualitas RBA. Selain itu temuan Izzaty (2011) bahwa kualitas SDM berpengaruh positif terhadap anggaran berbasis kinerja. Walaubagaimanapun, hasil penelitian Tantriani dan Puji (2012) berbeda dengan temuan kedua peneliti di atas. Penelitian Tantriani dan Puji (2012) menunjukkan bahwa kualitas SDM tidak berpengaruh terhadap kualitas laporan keuangan pemerintah daerah. Karenanya, kompetensi SDM berkaitan dengan efektivitas pelaksanaan SPIP yang selanjutnya menentukan kualitas laporan keuangan. Hipotesis penelitian adalah:

H2: Pelaksanaan SPIP yang efektif memediasi pengaruh kompetensi SDM terhadap kualitas laporan keuangan.

Komitmen sebagai keterikatan relatif dari suatu individu dengan suatu organisasi tertentu dan sebagai kekuatan relatif dari suatu individu untuk terlibat dalam suatu organisasi tertentu (Porter et al., 1974). Komitmen karyawan ditunjukkan oleh sikap loyal dari karyawan secara terus menerus pada organisasi untuk keberhasilan organisasinya (Mowday et al., 1982). Pendapat Robbins (1990; 2001) bahwa komitmen organisasi wujud seorang karyawan terkait dengan organisasi dalam mencapai tujuannya dan berniat memelihara keanggotaan di organisasi tersebut. Bedasarkan pendapat Robbins (1990; 2001) ini maka komitmen organisasi dapat diartikan sebagai suatu keinginan yang kuat untuk menjadi anggota organisasi. Keinginan ini sebagai pendorong seseorang dalam mengoptimalkan kemampuannya untuk mencapai tujuan organisasinya. Penyusun laporan keuangan yang memiliki komitmen yang tinggi tentu akan bekerja dengan optimal agar pelaksanaan SPIP 
menjadi efektif sehingga laporan keuangan yang disusun sesuai dengan ketentuan yang ditetapkan. Untuk itu hipotesis penelitian yang diajukan adalah:

H3: Pelaksanaan SPIP yang efektif memediasi pengaruh komitmen kerja karyawan terhadap kualitas laporan keuangan.

Menurut Ronen dan Livingstone (1975) bahwa motivasi pegawai akan meningkat jika memperkirakan tujuan yang ditetapkan dapat dicapai dan pencapaian tujuan tersebut memberi manfaat pada dirinya. Ini menunjukkan bahwa karyawan yang tidak mampu dalam bekerja maka motivasi kerjanya rendah. Motivasi kerja individu akan tinggi jika tujuan yang ia kerjakan dapat memenuhi kebutuhan pribadinya. Jenis motivasi adalah motivasi intrinsik dan motivasi ektrinsik. Hasil penelitian bahwa manajer bisa meningkatkan kinerjanya apabila didukung oleh motivasi intrinsik maupun motivasi ektrinsik (Ferris, 1977; Rockness, 1977). Penelitian lain di sektor publik yang dilakukan Shields dan Shields (1998) membuktikan bahwa motivasi berpengaruh terhadap peningkatan kinerja. Sejalan hasil temuan di atas Gibson et al., (1997) menyatakan bahwa motivasi yang kuat jika ada dalam pegawai maka dapat menghasilkan kinerja yang baik. Karena karyawan sebagai pelaksna SPIP untuk menyusun laporan keuangan maka hipotesis penelitian adalah:

H4: Pelaksanaan SPIP yang efektif dapat memediasi pengaruh motivasi karyawan terhadap kualitas laporan keuangan.

\section{Hubungan Dukungan Pimpinan, Kualitas SDM, Efektivitas SPIP dan Laporan} Keuangan

Kepemimpinan berkaitan dengan pengaruh dan motivasi. Pemimpin yang efektif yaitu pemimpin yang dapat mempengaruhi dan memotivasi pengikut dalam pencapaian tujuan organisasi. Menurut Pearson (1986) bahwa seorang pemimpin merupakan pemberi motivasi kepada karyawan. Kepemimpinan merupakan proses mempengaruhi dalam menginterprestasikan kejadian bagi pengikutnya dan mengorganisir kegiatan untuk mencapai sasaran, memelihara hubungan kerjasama dari kelompok kerja, memperoleh dukungan atau dapat bekerjasama dengan orang-orang di luar kelompok atau organisasi. Manakala pendapat Wallis dan Dollery (2015) bahwa pemimpin sepatutnya bertindak membantu, 
bekerjasama, memberi, dan memahami hubungan kerja antara atasan dan bawahan.

Dukungan pimpinan dalam mensosialisasikan, menerapkan, dan mengarahkan orang lain untuk melakukan perubahan diperlukan dalam organisasi. Dukungan pimpinan berpengaruh pada perilaku bawahannya melalui perubahan pola kerja dari bawahan yang menyesuaikan dengan pola kerja pemimpinnya. Mengacu pada peran pimpinan maka pimpinan tidak berhubungan secara langsung dengan pelaksanaan SPIP dan proses penyusunan laporan keuangan tetapi pimpinan berhubungan langsung dengan karyawan (SDM) melalui perubahan pola kerja yang berbasis kompetensi, komitmen dan motivasi. Karena dukungan pimpinan hanya berhubungan langsung dengan kompetensi SDM, komitmen kerja karyawan, dan motivasi karyawan maka hipotesis yang diajukan adalah:

H5: Dukungan pimpinan pada pelaksanaan SPIP yang efektif berpengaruh terhadap kualitas laporan keuangan dengan kompetensi SDM, komitmen kerja karyawan, dan motivasi karyawan sebagai variabel intervening

\section{METODE PENELITIAN}

Desain penelitian ialah rencana induk mengenai teknik dan prosedur untuk mengumpulkan data dan menganalisis data dari sampel (Zikmund, 1994). Menurut Babbie (1986) desain penelitian berkaitan dengan jenis penelitian. Jenis penelitian terdiri dari eksplorasi, deskriptif, dan uji hipotesis (Sekaran, 2000). Mengacu pendapat di atas maka penelitian ini merupakan penelitian deskriptif dan uji hipotesis.

Pengumpulan data menggunakan teknik survey. Pengumpulan data dengan teknik survey dapat melalui tatap muka dan kuesioner (Sekaran, 2000). Jika menggunakan kuesioner maka pengumpulan data dapat dilakukan secara pengiriman kuesioner dan wawancara (Emory \& Cooper, 1991; Miller, 1991). Penelitian ini mendistribusikan kuesioner kepada individu penyusun laporan keuangan Perguruan Tinggi Negeri (PTN) di Jateng dan DIY sebanyak 15 PTN (website http://www.ptn di jawa tengah dan diy). Responden penelitian diperkirakan sebanyak 105 dimana setiap PTN respondennya sebanyak 7 orang yang terdiri dari: staf ahli PR2, Kepala Bagian Akuntansi atau Keuangan, Kepala Subbagian Pelaporan/Akuntansi, operator SAIBA, operator SIMAK-BMN, 
operator persediaan, dan operator Aplikasi Pelaporan Keuangan BLU/PTNBH. Pengiriman kuesioner mempunyai kelemahan yang perlu diminimumkan, seperti tingkat respon yang rendah dibandingkan metode lainnya (Miller, 1991; Zikmund, 1994) karenanya penelitian ini dilakukan secara sensus.

\section{Definisi dan Pengukuran Konstruk}

Penelitian ini menggunakan tujuh variabel penelitian, yaitu kualitas laporan keuangan, efektivitas SPIP, dukungan pemimpin, kompetensi SDM, komitmen kerja karyawan, dan motivasi karyawan. Konstruk untuk mengukur variabel penelitian menggunakan konstruk yang dikembangkan oleh peneliti. Peneliti menilai bahwa konstruk dari peneliti terdahulu mengadopsi konstruk untuk perusahaan privat sedang penelitian ini mengukur institusi pemerintah. Konstruk variabel penelitian menggunakan skala likert 5 .

Karakteristik laporan keuangan pemerintah, yaitu: relevan; andal; dapat dibandingkan; dan dapat dipahami. Kualitas laporan keuangan adalah tingkat keandalan informasi yang tersedia dalam laporan keuangan. Terdapat 10 item pertanyaan dalam kuesiuner kualitas laporan keuangan tetapi untuk mengukur konstruk kualitas laporan keuangan hanya 9 item pertanyaan. Item pertanyaan nomor 10 kebalikan dari item pertanyaan nomor 4 (empat) yang bertujuan untuk mentes keseriusan responden dalam menjawab kuesioner.

Sistem Pengendalian Intern Pemerintan (SPIP) adalah proses yang integral pada tindakan dan kegiatan yang dilakukan secara terus menerus oleh pimpinan dan seluruh pegawai untuk memberikan keyakinan memadai atas tercapainya tujuan organisasi melalui kegiatan yang efektif dan efisien, keandalan pelaporan keuangan, pengamanan aset negara, dan ketaatan terhadap peraturan perundang-undangan. Efektivitas SPIP adalah tingkat pelaksanaan SPIP. Terdapat 12 item pertanyaan dalam kuesioner efektivitas SPIP tetapi untuk mengukur konstruk efektivitas SPIP hanya 11 item pertanyaan. Item pertanyaan nomor 12 kebalikan dari item pertanyaan nomor 3 (tiga) yang bertujuan untuk mentes keseriusan responden dalam menjawab kuesioner.

Pemimpin sepatutnya bertindak membantu, bekerjasama, memberi, dan memahami hubungan kerja antara atasan dan bawahan (Covey, 1990). Dukungan pimpinan adalah tingkat perhatian pimpinan dalam proses pertanggungjawaban agar 
laporan keuangan memiliki kualitas yang tinggi melalui pelaksanaan SPIP. Kontruk dukungan pimpinan diukur dengan 5 (lima) item pertanyaan.

SDM merupakan faktor dominan yang mempengaruhi kualitas laporan keuangan. Hal ini karena SDM yang menjalankan atau mengoperasional semua perangkat penyusunan laporan keuangan. Penelitian ini melihat SDM dari kompetensi, komitmen dan motivasi. Kompetensi SDM adalah kemampuan dan keahlian dari individu dalam penyusun laporan keuangan. Terdapat 4 (empat) item pertanyaan untuk mengukur konstruk kompetensi SDM.

Komitmen ditunjukkan oleh sikap loyal karyawan untuk keberhasilan organisasinya (Mowday et al., 1982). Pendapat Robbin dan Barnwell (1998) komitmen merupakan wujud seorang karyawan terkait dengan pencapai tujuan organisasi dan berniat memelihara keanggotaan di organisasi tersebut. Penelitian ini mendefinisikan komitmen kerja karyawan adalah sebagai suatu keinginan yang kuat untuk menjadi anggota bagian akuntansi/bagian keuangan untuk menghasilkan laporan keuangan yang berkualitas. Terdapat 6 (enam) item pertanyaan untuk mengukur konstruk komitmen kerja karyawan.
Motivasi karyawan merupakan dorongan pada individu untuk melakukan sesuatu dalam organisasi. Individu melaksanakan tugas dengan harapan mendapat imbalan, kenaikan pangkat, pujian/penghargaan, menunjukkan prestasi, dan mengaktualisasikan diri. Motivas karyawan adalah sebagai suatu dorongan ke atas diri karyawan untuk melaksanakanan tugas secara maksimal untuk menghasilkan laporan keuangan yang berkualitas. Kontruk motivas karyawan diukur dengan 7 (tujuh) item pertanyaan.

\section{Pengujian Hipotesis}

Penelitian ini merupakan penelitian deskriptif dan uji hipotesis. Analisis deskriptif menjelaskan tinggi rendah dengan kriteria rata-rata teoritis, yaitu nilai tiga. Jawaban responden dari item-item pertanyaan dari kontruk tidak dijumlahkan tetapi dijadikan rata-rata. Statistik regresi berhirarki digunakan untuk menguji hipotesis dengan bantuan program warp PLS versi 2.00. Persyaratan teknik statistik regresi adalah data harus normal dan tidak terjadi multikolinearitas, heteroskedastisitas, dan autokorelasi. Model fit/baik (goodness of fit) menggunakan nilai F-hitung dan kekuatan model dengan nilai determinan regresi $\left(R^{2}\right)$. Penerimaan atau penolakan hipotesis menggunakan nilai t-hitung. 
HASIL PENELITIAN DAN Pearson dari suatu item pertanyaan kurang PEMBAHASAN

\section{Tingkat Respon dan Karakteristik \\ Sampel}

Kuesioner yang dikirim kepada responden sebanyak 105 set dan kuesioner yang dikembalikan kepada peneliti sebanyak 98 set (93,33 persen). Kuesioner yang kembali terdapat 31 kuesioner yang tidak dipakai karena kuesioner tidak diisi (kosong), kuesioner tidak lengkap, dan kuesioner yang diisi secara tidak serius. Kuesioner yang diterima dan dapat digunakan untuk analisis lebih lanjut sebanyak 67 set. Ini menunjukkan tingkat respon sebesar 63,81 persen (Tabel 1 dalam lampiran). Tingkat respon penelitian ini sangat tinggi jika dibandingkan dengan tingkat respon survei secara umum di Indonesia, yaitu sekitar 10-20 persen (Kurnianingsih \& Indriantoro, 2001).

\section{Hasil Uji Kualitas Data}

Kualitas data ditinjau dari tingkat validitas data dan reliabilitas data. Validitas data diuji dengan menggunakan nilai koefisien Pearson. Kriteria data dinyatakan valid jika nilai koefisien Pearson lebih besar daripada 0,50. Hal ini karena nilai koefisien Pearson $\pm 0,50$ atau lebih tinggi adalah signifikan secara praktik. Jika koefisien dari 0,50 maka item pertanyaan tersebut dikeluarkan dari kuesioner (tidak diolah lebih lanjut). Reliabilitas data diuji dengan menggunakan nilai koefisien cronbach alfa $(\alpha)$. Kriteria data dinyatakan reliabel jika nilai koefisien cronbach alfa lebih besar daripada 0,70 (Nunnally, 1978). Ini bermakna kontruk jika digunakan berulangulang pada objek yang sama akan memberi hasil yang sama (Babbie, 1986).

Hasil uji statistik atas korelasi keseluruhan item pertanyaan terdapat koefisien korelasi lebih kecil dari 0,40, yaitu pertanyaan nomor 4 dari variabel motivasi kerja karyawan dengan nilai koefisien korelasi sebesar 0,38. Menurut Sugiyono (1999) pertanyaan nomor 4 tidak dapat mengukur konstruk variabel motivasi kerja karyawan.

Hasil uji validitas menunjukkan kriteria validitas, yaitu nilai koefisien Pearson lebih besar 0,50 telah terpenuhi. Ini berarti, data kualitas laporan keuangan, efektivitas SPIP, dukungan pimpinan, kompetensi SDM, komitmen kerja karyawan, dan motivasi karyawan dapat dinyatakan valid atau absah. Pula, hasil uji reliabilitas menunjukkan kriteria reliabilitas, yaitu nilai koefisien cronbach alfa lebih besar daripada 0,70 telah terpenuhi. Ini 
berarti reliabilitas data dari kualitas laporan keuangan, efektivitas SPIP, dukungan pimpinan, kompetensi SDM, komitmen kerja karyawan, dan motivasi karyawan dapat dinyatakan reliabel (dapat dipercaya) karena kontruk yang digunakan mempunyai konsistensi yang baik.

\section{Deskripsi Variabel Penelitian}

Deskripsi variabel penelitian menjelaskan keadaan tinggi atau rendahnya nilai variabel penelitian. Kriteria tinggi atau rendah suatu variabel sebesar 3,00 yaitu nilai rata-rata teoritis sklala likert. Statistik deskriptif (Tabel 2) menunjukkan bahwa rata-rata kualitas laporan keuangan sebesar 3,15. Hal ini menunjukkan sebagian besar PTN di Jawa Tengah dan DIY telah menyusun laporan keuangan yang berkualitas. Hal ini ditunjang oleh memadainya efektivitas SPIP dimana tingkat rata-rata efektivitas SPIP menunjukkan sebesar 3,42. Efektivitas SPIP yang tinggi dan laporan keuangan yang berkualitas tidak lepas dari peran karyawan yang memiliki komitmen dan motivasi kerja yang tinggi, yaitu tingkat rata-rata komitmen kerja karyawan menunjukkan sebesar 3,14 dan tingkat rata-rata motivasi karyawan menunjukkan sebesar 3,26. Kualitas laporan keuangan akan lebih meningkat jika operator memiliki kompetensi yang tinggi dan mendapat dukungan pimpinan yang kuat.

\section{Korelasi Parsial}

Suatu variabel memiliki hubungan dengan varibel lain jika nilai koefisien korelasi ( $r$ ) lebih besar daripada 0,10 (Kerlinger, 1986). Secara umum, nilai $r$ sebesar 0,16 sudah memadai untuk tingkat signifikan 0,05 tetapi jika nilai $r$ di atas 0,80 maka terdapat multikolinearitas pada hubungan variabel penelitian (Gujarati, 2003) sedang menurut Hair et al. (1998) terdapat multikolinearitas jika nilai $r$ di atas 0,90. Hasil uji korelasi (Tabel 3) menunjukkan terdapat hubungan positif antara efektifitas SPIP dan kualitas laporan keuangan dengan koefisien korelasi sebesar 0,37. Selain itu, efektifitas SPIP berkorelasi secara positif dengan kompetensi SDM ( $r$ : $0,51)$, komitmen kerja karyawan $(r: 0,28)$, dan motivasi karyawan ( $r: 0,73)$. Ini mengindikasikan efektifitas SPIP menjadi mediasi dari hubungan antara kompetensi SDM, komitmen kerja karyawan, dan motivasi karyawan dengan kualitas laporan keuangan. Manakala dukungan pimpinan tidak berkaitan langsung dengan kualitas laporan keuangan ataupun efektifitas SPIP tetapi berkorelasi melalui komitmen kerja karyawan dengan koefisien korelasi sebesar 
0,67 sedang dukungan pimpinan tidak berhubungan dengan kompetensi SDM dan motivasi karyawan.

\section{Uji Asumsi Multivariat}

Pengujian hipotesis menggunakan teknik statistik regresi berhirarki karena penelitian ini melihat hubungan antara satu variabel dependen dengan beberapa variabel independen (Hair et al., 1998). Terdapat empat persyaratan teknik statistik regresi, yaitu: data harus normal dan tidak terjadi multikolinearitas, heteroskedastisitas, dan autokorelasi. Hasil uji asumsi multivariat menunjukkan: pertama: data besifat normal karena garis diagonal atau kerve berbentuk genta merupakan perwujudan dari distribusi normal. Kedua, data tidak terjadi multikolinearitas karena nilai tolerans/VIF berada di atas nilai kriteria, yaitu: tolerans di atas 0,10 dan nilai VIF di bawah 10. Ketiga, data penelitian juga bebas dari heteroskedastisitas karena penyebaran data berada di atas atau di bawah nilai kosong (nol) pada sumbu Y dan tidak membentuk pola tertentu. Keempat, data tidak terjadi autokorelasi dimana nilai Durbin-Watson $(d)$ sebesar 1,59 $(1.47<1,59<5,53)$.

\section{Pengujian Model Mediasi}

Menurut Ghozali (2001) model penelitian dinyatakan fit/baik (goodness of fit) jika nilai $F$-hitung lebih besar daripada 1,96 (F-tabel) atau nilai signifikan pada 5 persen dan kekuatan model tercermin pada nilai determinan regresi $\left(\mathrm{R}^{2}\right)$. Hasil pengujian model mediasi pada Tabel 4 dan Tabel 5 menunjukkan estimasi model (1), model (2), dan model 3 menunjukkan telah terpenuhinya goodness of fit. Model hubungan efektivitas SPIP dengan kualitas laporan keuangan adalah layak $(\mathrm{F}=6,49)$ dengan kekuatan model 39 persen. Hubungan antara kompetensi SDM, komitmen kerja karyawan dengan motivasi karyawan dengan efektivitas SPIP memiliki model yang baik $(\mathrm{F}=57,71)$ dengan kekuatan model 54 persen. Manakala model hubungan dukungan pimpinan dengan efektivitas SPIP yang dimediasi oleh kompetensi SDM, komitmen kerja karyawan dengan motivasi karyawan dapat dinyatakan fit/baik $(\mathrm{F}=31,03)$ dengan kekuatan model 32 persen.

Tabel 4 juga menunjukkan bahwa efektivitas SPIP berkorelasi dengan kualitas laporan keuangan pada signifikansi 10 persen $(t=2,97, \quad(\beta)=0,33)$ dan Tabel 5 mengidentifikasikan bahwa dukungan pimpinan sangat berkaitan dengan kualitas SDM khususnya kompetensi SDM $(t=5,57$, 
$\beta=0,57)$, komitmen kerja karyawan $(\mathrm{t}=8,54$, $\beta=0,73)$ dan motivasi karyawan $(\mathrm{t}=7,35$, $\beta=0,67)$. Melihat kaitan antara kualitas SDM dengan efektivitas SPIP maka komitmen kerja karyawan sangat tinggi $(\mathrm{t}=6,31$, $\beta=0,65)$ dan motivasi karyawan signifikan pada 10 persen $(t=2,23, \beta=0,35)$. Hasil yang tidak memuaskan (tidak signifikan) terjadi pada hubungan kompetensi SDM dengan efektivitas SPIP $(t=1,32, \beta=0,14)$. Dukungan pimpinan tidak berhubungan langsung dengan pelaksanaan SPIP yang efektif. Ini bermakna kualitas SDM menjadi mediasi yang sempurna bagi hubungan antara dukungan pimpinan dengan efektivitas SPIP (Baron dan Kenny, 1986).

\section{Diskusi Temuan Penelitian}

Hasil pengujian dengan regresi berhirarki menunjukkan bahwa kualitas laporan keuangan tergantung pada efektivitas pelaksanaan SPIP. Laporan keuangan dinyatakan berkualitas jika berisi informasi yang andal sebagaimana tujuan dari penyusunan SPIP, yaitu keandalan laporan keuangan. Selain itu, temuan penelitian ini menunjukkan kompetensi SDM dan motivasi karyawan berdampak pada pelaksanaan SPIP yang efektiv dan keandalan laporan keuangan sedang komitmen kerja karyawan hanya berdampak pada efektivitas SPIP dan tidak berpengaruh pada kualitas laporan keuangan. SDM merupakan pengguna dari perangkatperangkat menyusun laporan keuangan termasuk SPIP. Temuan penelitian ini menunjukkan pentingnya kualitas SDM dalam pelaksanaan SPIP untuk penyusunan laporan keuangan yang berkualitas. Peran efektivitas SPIP menjadi mediator yang sempurna antara komitmen kerja karyawan dengan kualitas laporan keuangan. Pada hubungan kompetensi SDM dan motivasi karyawan dengan kualitas laporan keuangan peran pelaksanaan SPIP sebagai intervening sebagian (separa). Ini bermakna terdapat beberapa variabel lain yang mungkin menjadi pemediasi pada hubungan kompetensi SDM dan motivasi karyawan dengan kualitas laporan keuangan. Hasil penelitian yang berupa peran efektivitas SPIP dalam hubungan kualitas SDM dengan kualitas laporan keuangan sesuai dengan teori sikap dan perilaku, yaitu, penyusun laporan keuangan akan melaksanakan tugas secara perfek (sempurna) untuk menghasilkan laporan keuangan yang berkualitas jika individu (SDM) mempunyai, kompetensi, komitmen dan motivasi yang tinggi dengan dibantu perangkat sistem pengendalian intern pemerintah (SPIP) yang memadai. 
Dukungan pimpinan tidak berdampak langsung pada kualitas laporan keuangan tetapi harus melalui penempatan SDM yang berkualitas dan SPIP yang memadai. Pimpinan punya kuasa untuk mengatur dan menempatkan SDM baik dari segi kompetensi SDM, komitmen kerja karyawan, maupun dari segi motivasi karyawan. Selain itu, pimpinan punya kuasa untuk menyusun dan menetapkan SPIP yang digunakan dalam pengelolaan keuangan tetapi efektivitas pelaksanaan SPIP tergantung pada kualitas SDM sebagai pelaksana. Hasil penelitian ini sejalan dengan teori resources-based, yaitu pemanfaatan sumber daya yang optimal atau mensinkronkan sumber daya dengan baik sesuai porsinya maka akan memberikan kontribusi positif pada kualitas laporan keuangan (Barney, 1991; Henri, 2006). Ditinjau dari teori sikap dan perilaku bahwa pimpinan melaksanakan tugas berupa mengelola keuangan dan mempertanggungjawabkannya dengan baik maka perlu bertindak dengan optimal, yaitu harus memperhatikan berkualitas individu (SDM) yang memiliki kompetensi, komitmen dan motivasi yang tinggi serta menyusun sistem pengendalian intern pemerintah (SPIP) yang baik.

\section{KESIMPULAN DAN SARAN}

PTN di Jawa Tengah dan DIY telah menyusun laporan keuangan yang berkualitas dengan menerapkan SPIP yang baik. Penerapan SPIP ditunjang oleh komitmen kerja karyawan dan motivasi karyawan yang tinggi walaupun masih menggunakan kompetensi SDM yang rendah dan dukungan pimpinan yang belum optimal. Secara keseluruhan kualitas SDM dan pelaksanaan SPIP berperan penting dalam menjembatani dukungan pimpinan untuk mempertanggungjawabkan pengelolaan keuangan. Sesuai teori sikap dan perilaku pimpinan dalam mempertanggungjawabkan pengelolaan keuangan perlu dibantu karyawan yang memiliki: kompetensi dalam pelaporan keuangan, komitmen dalam bekerja, dan motivasi kerja yang tinggi. Karyawan dalam menyusun laporan keuangan perlu perangkat SPIP yang baik atau memadai.

Penelitian ini mempunyai beberapa keterbatasan yang dapat menjadi bahan pertimbangan bagi penelitian mendatang. Pertama, ukuran sampel yang kecil sehingga menggunakan statistik regresi berhirarki. Penelitian mendatang perlu ukuran sampel yang besar dan menggunakan SEM untuk memperkuat pengujian statistikal atas desain model penelitian. Kedua, sampel penelitian 
ini berasal dari PTN di Jawa Tengah dan DIY sehingga keputusan penelitian ini tidak dapat digeneralisasi ke instansi pemerintah non-PTN atau ruang lingkup yang lebih luas. Penelitian mendatang perlu dilakukan pada skop yang lebih luas atau dilakukan pada instansi pemerintah non-PTN untuk memperoleh keputusan yang lebih baik. Ketiga, penelitian ini tidak membedakan PTN di bawah Kementerian Riset, Teknologi, dan Pendidikan tinggi dan PTN di bawah Kementerian Agama. Penelitian mendatang perlu mempertimbangkan perbedaan tersebut agar responden bersifat homogen sehingga dapat memberikan keputusan yang kokoh. Keempat, penelitian ini menggunakan variabel SPIP dengan pendekatan efektivitas pelaksanaanya. Penelitian mendatang perlu menggunakan variabel SPIP dengan pendekatan desain SPIP untuk menggambarkan peran SPIP yang lebih komprehensif.

\section{DAFTAR PUSTAKA}

Babbie, E.R. (1986). Survey research methods. Wadsworth: Thomson Learning.

Barney, J. B. 1991. Firms resources and sustained competitive advantage. Journal of Management, 27: 625641.
Baron, R.M. dan Kenny, D.A. (1986). The moderator-mediator variable distinction in social psychological research: Conceptual, strategic, and statistical considerations. Journal of Personality and Social Psychological, $51,1173-1182$.

Cooper, D.R. dan Emory, W.C. (1995). Business research methods. 5th edition. Richard D. Irwin Inc.

Covey Stephen R, 1990, Principle-Centered Leadership ,New York: Fireside

Emory, W.C. dan Cooper, D.R. 1991; Business Reseach Methods. Revised Edition. Homewood, Illinois: Richard D. Irwin Inc.

Ferris, K.R. (1977). A test of the expectancy theory of motivation in an accounting environment. The Accounting Review. July: 605-721.

Ferris, K.R. (1977). Perceived environmental uncertainty and job satisfaction in the accounting environment. Accounting, Organizations and Society, 2, 23-28.

Ghozali, I. (2001). Aplikasi analisis multivariate dengan program SPSS. Edisi ke dua. Semarang: BP Universitas Diponegoro Semarang. 
Gibson, J.L., Ivancevich, J.M. dan Donnelly, Jr., J.H. (1997). Organizations: Behavior, structure, processes. Fifth Edition. Texas: Business Publications, Inc.

Gujarati, D. N. (2003). Basic econometrics. Fourth Edition. Boston: McGrawHill Co.

Hair, J.F., Andeson, R.E., Tatham, R.L. dan Black, W.C. (1998). Multivariate data analysis. Fifth Edition. New Jersey: Prentice-Hall, Upper Saddle River.

Hair, J.F., Andeson, R.E., Tatham, R.L. dan Black, W.C. (2006). Multivariate data analysis. Sixth Edition. New Jersey: Prentice-Hall, Upper Saddle River.

Henri, J.F. 2006. Management control systems and strategy: A resourcebased perspective. Accounting, Organizations, and Society, 31: 529558.

Ikatan Akuntan Indonesia (2012). Standar Pemeriksaan Akuntan Publik. IAI

Izzaty, Khairina Nur. (2011).Pengaruh Gaya Kepemimpinan dan Kualitas Sumber Daya Manusia Terhadap Penerapan
Anggaran Berbasis Kenerja Badan Layanan Umum. Semarang: Undip.

Kerlinger, F. N. (2003). Asas-asas penelitian behavioral. Cetakan Ke Sembilan. Yogyakarta: Gadjah Mada University Press.

Kerlinger, F.N. (1986). Foundations of Behavioral Research. Thied Edition. Holt, Rinehart and Winston Inc.

Kurnianingsih, R. dan N. Indriantoro. 2001. Pengaruh Sistem Pengukuran Kinerja dan Sistem Penghargaan terhadap Keefektifan Penerapan Teknik Total Quality Management: Studi Empiris pada Perusahaan Manufaktur di Indonesia. Jurnal Riset Akuntansi Indonesia, Vol. 4 (1): 28-43.

Miller, D. (1991). Stale in the saddle: CEO tenure and the match between organization and environment. Management Science, 37, 34-52.

Mowday, R.T, Steers R.M dan Porter,L.W. 1979. Measurement Commitment of Organizational. Journals Vocational Behavior 12 224-247

Mowday, R.T, Steers R.M dan Porter,L.W. 1982. Employee-organizational Linkage. New York Academic 
Nunnally, J.C. (1978). Psychometric Theory, 2st ed. New York: McGraw-Hill.

Pearson, G.J. (1986). Corporate culture as management tool. Management Accounting, November, 40-41.

Peraturan Badan Pemeriksa Keuangan Republik Indonesia No 1 tahun 2007 tentang Standar Pemeriksaan Keuangan Negara

Porter, L.W., Steers, R.M., Mowday, R.T., and Boulian, P.V. (1974). Organizational Commitment, Job Satisfaction, and Turnover among Psychiatric Technicians. Journal of Applied Psychology, 59(5), 603-609.

Purwaniati N, dan Subaweh I. 2011. Pengaruh Penerapan Standar Akuntansi Pemerintahan Terhadap Kualitas Laporan Keuangan. Jurnal Ilmiah Ekonomi Bisnis 13(1), 48 - 58

Robbin, S.P. (1990). Organizational theory: Structure, design and applications. Third Edition, Englewood Cliffs, NJ: Prentice Hall International.

Robbin, S.P. dan Barnwell, N. (1998). Organizational theory: Concepts and cases. Third Edition. Sydney: Prentice Hall Australia Pty Ltd.
Robbins, S.T. (2001). Organizational Behavior. Prentice Hall. New Jersey. Rockness, H.O. (1977). Expectancy theory in a budgetary setting: An examination. The Accounting Review. October: 671-685.

Ronen, J. and Livingstone, J.L. (1975). An expectancy theory approach to the motivational impact on budgeting. The Accounting Review. October: 671-685.

Sekaran, U. (2000). Research methods for business: A skill building approach, Second Edition, New York: John Wiley \& Sons, Inc.

Shields, J.F. and Shields, M.D. (1998). Antecedents of participative budgeting. Accounting, Organizations and Society. 23(1): 49-76.

Siti Mutmainah, Agus Purwanto, dan Sudarno (2013). Analisis FaktorFaktor Yang Mempengaruhi Kualitas Rencana Bisnis dan Anggaran (RBA). Universitas Diponegoro, Semarang.

Sugiyono (1999). Metode penelitian bisnis. Bandung: CV. Aljabar. 
Sukmaningrum, Tantriani dan Harto Puji, 2012. Analisis Faktor-faktor yang Mempengaruhi Kualitas Informasi Laporan Keuangan Pemerintah Daerah, Skripsi, Unpublished, Fakultas Ekonomika dan Bisnis Universitas Diponegoro. Semarang

Triandis, H.C. (1980). Attitudes and Attitudes Change. New York : John Willey and Sons.

Triandis, H.C. (1994). Culture and social behavior. New York: McGraw-Hill, Inc.

Wallis, J. dan Dollery, B. (2015). The impact of alternative stayles of policy leadership on direction of local governmant reform. International Journal of Social Economic; 32 (4): 291.

website http://www.ptn di jawa tengah dan diy.

Zikmund, W. G. (1994). Business research methods. 4th ed. The Dryden Press, Harcourt Brace College Publishers.

\section{LAMPIRAN}

\section{Kuesioner Penelitian}

Kualitas laporan keuangan
1. Saya meyakini nilai penerimaan/pendapatan dalam Laporan Realisasi Anggaran instansi kami.

2. Saya meyakini nilai belanja dalam Laporan Realisasi Anggaran instansi kami.

3. Saya meyakini nilai aset lancar dalam Laporan Posisi Keuangan (Neraca) instansi kami.

4. Saya meyakini nilai aset tetap dalam Laporan Posisi Keuangan (Neraca) instansi kami.

5. Saya meyakini nilai kewajiban dalam Laporan Posisi Keuangan (Neraca) instansi kami.

6. Saya meyakini nilai arus kas masuk dalam Laporan Arus Kas instansi kami.

7. Saya meyakini nilai arus kas keluar dalam Laporan Arus Kas instansi kami.

8. Saya meyakini Catatan atas Laporan Keuangan instansi kami telah memadai.

9. Saya meyakini bahwa Catatan atas Laporan Keuangan instansi kami telah mengungkapan secara mendalam.

\section{Efektivitas SPIP}

1. Pimpinan instansi kami tidak mentoleransi perilaku atau perbuatan yang tidak etis dalam pengelolaan keuangan instansi. 
2. Pengelola keuangan di instansi kami adalah individu-individu yang kompeten pada bidangnya.

3. Pimpinan instansi kami selalu memotivasi kami dalam melaksanakan tugas.

4. Pimpinan instansi kami selalu memberi arahan kepada kami dalam menjalankan tugas.

5. Pimpinan instansi kami dengan cepat menindak karyawan yang melanggar peraturan-peraturan instansi/pemerintah.

6. Pimpinan instansi kami memperhatikan teтиаn-teтиаn Auditor Internal/Satuan Pengawas Intern (SPI).

7. Instansi kami telah memiliki SOP dari kegiatan-kegiatan pokok pengelolaan keuangan instansi.

8. Pembuatan SOP dari kegiatan-kegiatan pokok pengelolaan keuangan instansi dikaitkan dengan proses penilaian risiko.

9. SOP dari kegiatan-kegiatan pokok pengelolaan keuangan instansi sudah ditetapkan secara tertulis.

10. Pelaksanaan SOP dari kegiatan-kegiatan pokok pengelolaan keuangan instansi dievaluasi secara periodik.

11. Pimpinan instansi kami mudah memperoleh informasi tentang pengelolaan keuangan.
Dukungan pimpinan

1. Pimpinan instansi kami siap sedia membantu pengadaan aplikasi sistem informasi pengelolaan keuangan.

2. Pimpinan instansi kami segera menyetujui kegiatan pelatihan/ workshop yang berkaitan dengan penyusunan laporan keuangan.

3. Karyawan yang terkait pengelolaan keuangan dengan senang hati untuk membantu pimpinannya.

4. Pimpinan instansi kami tidak ada jarak (merakyat) dengan para karyawan.

5. Karyawan merasa termotivasi/mendapat arahan ketika bincang-bincang dengan pimpinan instansi kami.

\section{Kompetensi SDM}

1. Operator/staf mumpuni/cakap/mampu dalam mengoperasional aplikasi sistem informasi pengelolaan keuangan.

2. Atasan langsung operator/staf memahami aplikasi sistem informasi pengelolaan keuangan tersebut.

3. Operator/staf dan atasan langsung memperoleh pelatihan yang cukup atas aplikasi sistem informasi pengelolaan keuangan.

4. Operator/staf dan atasan langsung memiliki latar belakang/ pengetahuan 
sesuai dengan tugas dan fungsi (tusi) saat sekarang.

Komitmen kerja karyawan

1. Karyawan pengelola keuangan instansi masuk dan pulang kantor sesuai peraturan/jadwal.

2. Karyawan pengelola keuangan instansi tidak pernah meninggalkan ruang kerja selama jam kerja.

3. Karyawan pengelola keuangan instansi senantiasa ada (tepat waktu) ketika diminta menghadap pimpinan.

4. Karyawan pengelola keuangan instansi menyelesaikan tugas dan fungsinya sesuai jadawal (tepat waktu).

5. Karyawan pengelola keuangan instansi selalu siap sedia menjalankan perintah di luar tugas dan fungsinya (tidak ngedumel/uring-uringan).

6. Karyawan pengelola keuangan instansi selalu berusaha menguasai tugas dan fungsinya.

Motivasi karyawan
1. Karyawan pengelola keuangan bekerja keras untuk menyelesaikan pekerjaannya sesuai waktu yang ditetapkan.

2. Karyawan pengelola keuangan yakin bahwa pekerjaannya selesai tepat waktu berdampak pada keinginannya (seperti naik jabatan).

3. Karyawan pengelola keuangan bekerja sebaik-baiknya agar menghasilkan output yang sempurna (optimal).

4. Karyawan pengelola keuangan merasa puas diri jika tugasnya berhasil dengan baik/sempurna.

5. Karyawan pengelola keuangan bekerja sebaik-baiknya karena merasa anggota lingkungan kerjanya.

6. Karyawan pengelola keuangan bekerja sebaik-baiknya karena atasannya akan menyukai dirinya atau memberi penghargaan dikemudian hari.

7. Karyawan pengelola keuangan yakin bahwa pekerjaannya selesai tepat waktu berarti membantu pencapaian tujuan instansinya.

Tabel 4.1

Tingkat Pengembalian Kuesioner Dan Tanggapan Yang Digunakan

\begin{tabular}{|l|c|c|}
\hline \multicolumn{1}{|c|}{ Keterangan } & Bilangan & Persen \\
\hline Populasi atau sampel & 105 & \\
\hline Kuesioner yang didistribusikan & 105 & 100 \\
\hline Tidak ada tanggapan/pengembalian & 7 & 6,67 \\
\hline
\end{tabular}




\begin{tabular}{|l|c|c|} 
Pengembalian kuesioner & 98 & 93,33 \\
\hline Kuesioner dikembalikan dan kosong & 7 & 6,67 \\
\hline Kuesioner yang tidak lengkap & 11 & 10,48 \\
\hline Responden menjawab tidak serius & 13 & 12,38 \\
\hline Kuesioner yang digunakan & 67 & 63,81 \\
\hline
\end{tabular}

Sumber: Data primer yang diolah.

\section{Tabel 2}

Deskripsi Variabel Penelitian

\begin{tabular}{lccccc}
\hline \multicolumn{1}{c}{ Variabel } & $\begin{array}{c}\text { Mini } \\
\text { mum }\end{array}$ & $\begin{array}{c}\text { Maksi } \\
\text { mum }\end{array}$ & $\begin{array}{c}\text { Rata-rata } \\
\text { Teoritis }\end{array}$ & $\begin{array}{c}\text { Rata-rata } \\
\text { Hitung }\end{array}$ & $\begin{array}{c}\text { Standar } \\
\text { Deviasi }\end{array}$ \\
\hline Kualitas laporan keuangan & 2,14 & 4,84 & 3 & 3,15 & 0,69 \\
Efektivitas SPIP & 2,08 & 4,69 & 3 & 3,42 & 0,71 \\
Dukungan pimpinan & 1,43 & 4,71 & 3 & 2,72 & 0,90 \\
Kompetensi SDM & 1,07 & 4,82 & 3 & 2,74 & 0,91 \\
Komitmen organisasi & 1,90 & 4,64 & 3 & 3,14 & 0,69 \\
Motivasi kerja karyawan & 1,94 & 4,50 & 3 & 3,26 & 0,66 \\
& & & & & \\
\hline
\end{tabular}

Tabel 3

Korelasi Antara Variabel Independen Dengan Variabel dependen

\begin{tabular}{|c|c|c|c|c|c|c|c|}
\hline $\begin{array}{c}\text { Variab } \\
\text { el }\end{array}$ & $\mathbf{l k}$ & ap & pi & dp & kk & ko & mk \\
\hline $\mathbf{l k}$ & 1 & $0,39^{* *}$ & $0,37^{* *}$ & 0,02 & $0,40^{* *}$ & 0,04 & $0,51^{* *}$ \\
\hline ap & & 1 & 0,09 & 0,16 & 0,23 & $-0,07$ & 0,19 \\
\hline pi & & & 1 & $-0,15$ & $0,51^{* *}$ & $0,28^{*}$ & $0,73^{* *}$ \\
\hline dp & & & & 1 & $-0,21$ & $0,67^{* *}$ & $-0,15$ \\
\hline kk & & & & & 1 & $-0,24$ & $0,57^{* *}$ \\
\hline ko & & & & & & 1 & $-0,21$ \\
\hline $\mathbf{m k}$ & & & & & & & 1 \\
\hline ** Signi & & & & & & Signif & an pada \\
\hline \multicolumn{4}{|c|}{$\begin{array}{l}\text { lk = kualitas laporan keuangan } \\
\text { pi = efektivitas SPIP } \\
\text { dp = dukungan pimpinan }\end{array}$} & \multicolumn{4}{|c|}{$\begin{array}{l}\text { kk = kompetensi SDM } \\
\text { ko = komitmen kerja karyawan } \\
\text { mk = motivasi karyawan }\end{array}$} \\
\hline
\end{tabular}


Tabel 4

Hubungan Kualitas SDM, Efektivitas SPIP, dan Kualitas Laporan Keuangan

\begin{tabular}{|c|c|c|c|c|c|c|}
\hline \multirow{3}{*}{ Variabel Dependen } & \multirow{2}{*}{\multicolumn{2}{|c|}{$\begin{array}{c}\text { Kualitas } \\
\text { Laporan } \\
\text { Keuangan }\end{array}$}} & \multicolumn{4}{|c|}{ Efektivitas SPIP } \\
\hline & & & \multicolumn{2}{|c|}{ Model 1} & \multicolumn{2}{|c|}{ Model 2} \\
\hline & $\begin{array}{c}\text { Beta } \\
(\beta)\end{array}$ & t-hitung & $\begin{array}{c}\text { Beta } \\
(\beta)\end{array}$ & t-hitung & $\begin{array}{c}\text { Beta } \\
(\beta)\end{array}$ & t-hitung \\
\hline Nilai F & \multicolumn{2}{|c|}{$6,49 *$} & \multicolumn{2}{|c|}{$37,71 *$} & \multicolumn{2}{|c|}{$31,03 *$} \\
\hline $\mathrm{R}^{2}$ & \multicolumn{2}{|c|}{0,39} & \multicolumn{2}{|c|}{0,54} & \multicolumn{2}{|c|}{0,32} \\
\hline Efektivitas SPIP & 0,33 & $2,97 * * *$ & & & & \\
\hline Kompetensi SDM & & & 0,14 & 1,32 & 0,12 & 0,94 \\
\hline $\begin{array}{l}\text { Komitmen kerja } \\
\text { karyawan }\end{array}$ & & & 0,65 & $6,31 *$ & 0,29 & $1,98 * * *$ \\
\hline Motivasi karyawan & & & 0,35 & $2,23 * * *$ & 0,31 & $1,91 * * *$ \\
\hline Dukungan pimpinan & & & & & 0,14 & 0,84 \\
\hline
\end{tabular}

* Signifikan pada 0,01 .

$* * *$ Signifikan pada 0,10 .

\section{Tabel 5}

Hubungan Dukungan Pimpinan dan Kualitas SDM

\begin{tabular}{|c|c|c|c|c|c|c|}
\hline \multirow[t]{2}{*}{ Variabel Dependen } & \multicolumn{2}{|c|}{$\begin{array}{c}\text { Kompetensi } \\
\text { SDM }\end{array}$} & \multicolumn{2}{|c|}{$\begin{array}{c}\text { Komitmen } \\
\text { Kerja } \\
\text { Karyawan }\end{array}$} & \multicolumn{2}{|c|}{$\begin{array}{c}\text { Motivasi } \\
\text { Karyawan }\end{array}$} \\
\hline & $\begin{array}{c}\text { Beta } \\
(\beta)\end{array}$ & $\begin{array}{c}t- \\
\text { hitung }\end{array}$ & $\begin{array}{c}\text { Beta } \\
(\beta)\end{array}$ & $\begin{array}{c}t- \\
\text { hitung }\end{array}$ & $\begin{array}{c}\text { Beta } \\
(\beta)\end{array}$ & $\begin{array}{c}t- \\
\text { hitung }\end{array}$ \\
\hline Nilai F & \multicolumn{2}{|c|}{$47,52 *$} & \multicolumn{2}{|c|}{$72,86 *$} & \multicolumn{2}{|c|}{$54,03 *$} \\
\hline $\mathrm{R}^{2}$ & \multicolumn{2}{|c|}{0,41} & \multicolumn{2}{|c|}{0,53} & \multicolumn{2}{|c|}{0,45} \\
\hline Dukungan pimpinan & 0,57 & $5,57 *$ & 0,73 & $8,54 *$ & 0,67 & $7,35^{*}$ \\
\hline
\end{tabular}

